\title{
Trigonometrical Survey of India and Naming of Peak XV as Mt. Everest
}

\author{
Shrikant Mishra*, Sandeep Singh**, Parampreet Singh*** \\ and Bhavesh Trikamji****
}

(Received 06 September, 2014)

\begin{abstract}
Mt. Everest (height 29,029 feet above sea level) may be considered as one of the jewels of Asian region. Many people credit the discovery of the peak and its height to Sir George Everest. However, Radhanath Sikdar, an Indian native, and Andrew Waugh, the subsequent Surveyor General, deserve the true recognition. The paper will explore the old materials to give more accurate details on the discovery of Mt. Everest. Most of the data was gathered from the book EVEREST the Man and the Mountain written by J. R. Smith. Other sources include Histnett, Toxnet, PubMed, Unlocking the Archives, Gobar Times, Professional Surveyor Archives, Royal Geographical Society, Survey of India, and UCLA and USC Libraries. The Great Trigonometric Survey of India took place over a 50 year time period and resulted in the discovery of Mt. Everest. Although Sir George Everest completed substantial sections of the Great Trigonometric Survey of India, it was Radhanath Sikdar who actually discovered Mt. Everest.
\end{abstract}

India

Key words: Andrew Waugh, Mt Everest, Radhanath Sikdar, Sir George Everest, Survey of

\section{INTRODUCTION}

The Tibetan people knew of Mt. Everest, the highest peak in the world, about 280 years before British explorers in India made its discovery public. Mt. Everest was known by many names at that time, such as Mt. Qomolangma after the Tibetan Goddess of Earth and Mt. Sägarmāthā meaning "forehead of the sky" according to the Nepalese.

It was referred to as Peak XV when it was first discovered during the Great Trigonometrical Survey of India (GTS) and was ultimately renamed Mt. Everest. This was a dedication to Sir George Everest, who was the pioneering Surveyor General of British India. The entire endeavour of discovering Mt. Everest included formidable physical, technical, political, and psychological obstacles. The hazards of completing the survey contributed to the various medical and neurological illnesses that Everest experienced during his time in India (Mishra and Trikmaji, 2014, pp. 42-49).

\section{Sir George Everest (1790 - 1866)}

Colonel Sir George Everest (July 4, 1790 - December 1, 1866) was born at Gwernvale Manor, near Crickhowell, Powys in Wales. He attended the military academy at Woolwich where his strength rested in mathematics. He was appointed as assistant to Colonel Lambton in the

\footnotetext{
*Department of Neurology, Keck School of Medicine, USC, California, USA, Corresponding Address: 16111 Plummer Street, North Hills, California, USA, 91343; Email: smishra@usc.edu

**Department of Neurology, VA Greater Los Angeles HCS, Los Angeles, California, USA

***Department of Neurology, Harbor-UCLA Medical Center, Torrance, California, USA

****Department of Neurology, Olive View UCLA Medical Center, Sylmar, California, USA
} 
Great Trigonometrical Survey of the Indian subcontinent in 1818 . However, due to the untimely death of Colonel Lambton in 1823, he became the Superintendent of the survey and later the Surveyor General of India. He is credited with surveying India along the meridian arc starting from south of India to Nepal. Before he could make his way to Mt. Everest, he retired due to his failing health in 1843. In England, he was distinguished as a "Fellow of the Royal Geographical Society" and knighted in 1861. He became the Vice-President of the Royal Geographical Society a year later. In 1866, his life came to an end in Greenwich and he was buried at St. Andrews Church in Hove (Kunzru, 2013).

\section{The Great Trigonometrical Survey of INDIA}

\begin{abstract}
"All they wanted to do was mark an arc across India to prove their point. Little did these nineteenth century adventurers realise that their mammoth journey would revolutionise the future of geography in India (Gobar Times)."
\end{abstract}

In the year 1802, British surveyor Colonel William Lambton began one of the greatest "Geodetic" journeys undertaken in scientific history, referred to as the Great Trigonometrical Survey of India (GTS). The GTS lasted 50 years throughout colonial India. The survey was part of 'The Great Arc Experiment' to prove that the Earth was a spheroid. Col. Lambton initiated the GTS of India as part of the Great Arc Experiment to determine the length of an arc along a chosen longitude at a one-degree latitude separation. Lambton employed the technique of triangulation to measure the length of the arc, enabling him to identify three visible reference points at specific heights as the corners of a triangle. By knowing the exact distance between two of these points and then measuring the angles made at each by the respective lines of sight with the third reference point, the distance and position of the third point could be deduced through trigonometry. One side of this triangle then served as the baseline for a second triangle with a new reference point. With this technique, he was able to make a chain of such triangles across the length of India. Equipped with carriages, palanquins, tents and a massive half-tonne theodolite (an instrument for making trigonometrical measurements), Lambton and his troupe of surveyors began their vast quest on April 10, 1802. The first baseline measurement between St. Thomas Mount in Madras and a location 7.5 $\mathrm{km}$ south of St. Thomas Mount alone took 57 days to complete.

The total north-south distance of $2,575 \mathrm{~km}$ was the longest measurement of the earth's surface ever attempted. Trees and houses had to be removed for clearing a line of sight for measurements; sometimes entire villages were razed. The surveyors also faced other obstacles such as malarial fevers, dysentery, snakebites, floods, extreme weathers, treacherous hills, thick jungles, swamps, dacoits, and even battles with local tribes. Furthermore, every observation required measurements on top of tall structures such as hilltops and temple "gopurams." When natural structures were unavailable, 30-metre high bamboo structures were erected.

George Everest joined the survey 1818. Everest and Col. Lambton shared the same passion for their work and were thus able to convince the skeptical British government to continue funding the project. They also diplomatically negotiated with local kings to allow them to pass through native lands to take measurements. Unfortunately on January $20^{\text {th }}, 1823$, Col. Lambton died in an accident at Hinganghat on his way to Nagpur. He passed away at the age of 70 before fulfilling his dream of completing the survey. As a result, Everest, who was next in line of command, took on this responsibility. As the new Surveyor General, Everest proposed to cover the length and breadth of India with a "gridiron" of triangular chains against the initial network of triangulations conceived by Lambton. He also introduced the 
"ray tracing" method for locating stations. Despite his own medical conditions, he continued the measurements of the arc and reached the Tropic of Cancer on May, 1824. However, Everest later was forced to leave for London for medical treatment due to his deteriorating health.

Unfortunately, in Everest's absence no significant progress was made in the survey. Upon his return, Everest recruited additional staff. Two of the important new staff members were Andrew Waugh and Renny Taylor. Everest and his team planned to complete the survey with 35 measurement stations between Sironj in the South and Dehradun in the North. In Sironj, Everest measured another baseline of $38,410 \mathrm{ft}$. and completed the observation at Kalianpura by November, 1824. The northern-most baseline of the Great Arc was measured in an area near Dehradun from 1834 - 1835. Since most of the areas were plains, scaffolding masts and masonry towers of 50 to 70 feet were constructed. Assisted by Waugh, Everest connected the Dehradun base with that of Sironj in February, 1837 thirteen years since the first measurement made at Sironj. With a passion for accuracy, Everest and his team made calculations of length from the Dehradun base to the Sironj base differing by only 7.2 feet compared to today's standards (Lee, 1899, p. 78).

Everest's inspirational work and dedication pioneered Geodetic Measurements in India leading many to regard him as "The Father of Indian Geodesy" (Kulkarni). With the efforts of Everest, Andrew Waugh, and Col. Walker, the longitudinal series of the Great Trigonometrical Survey was completed in 1866. In his memoirs on the GTS, Clement R. Markham concluded, "The story of Great Trigonometrical Survey when fittingly told will form one of the proudest pages in the history of English domination in the East." Everest retired in 1843 and his successor Andrew Waugh continued mapping. His work was mainly concerned with triangulation between the Great Arc Series (from Dehradun and onwards) and the
Calcutta and North-eastern Himalayan Series, which included the mapping and deducing of the 79 Himalayan peaks (Phillimore, 1954). In 1861, after Andrew Waugh retired, Col. Walker became the Superintendent of the GTS and continued the task of computing triangulation data. The actual measurements of GTS were completed around 1866. In 1877, the GTS merged into a larger organization called the Survey of India with Col. Walker as its first Surveyor General. The new organization took over the task of mapping the areas that were left out, eventually covering the entire country. The Survey of India still exists today as India's current central engineering agency.

\section{Discovery of Mount Everest}

One day in 1852 in British-ruled India, a young man burst into an office in the northern Dehradun hill town and announced to his boss:

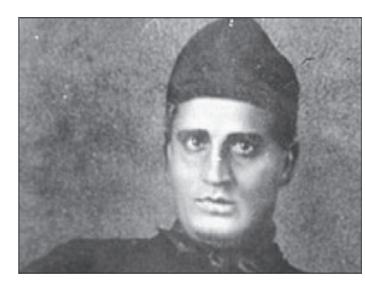
"Sir, I have discovered the highest mountain in the world!" This young man was Radhanath Sikdar (Kulkarni).

After four long and strenous years of unscrambling mathematical data, Radhanath Sikdar determined the height of the Himalayan Peak XV at 29,002 feet (8,840 metres). However, this news was announced to the world only after another four years. Surveyor General Andrew Waugh was uncertain about the height of Peak XV even though it had been accurately surveyed from six different stations in the plains. The highest peak today stands at 29,035 feet ( 8,850 metres) above the sea level. Sikdar's feat is now part of the Great Arc Exhibition in London's vibrant Brick Lane. However, in the eyes of many Indians Radhanath Sikdar, was the person who "technically discovered" Peak XV, and yet was lost in the pages of history (Phillimore, 1954). 
Radhanath Sikdar, a mathematician from Calcutta, was described by Col. George Everest as:

\begin{abstract}
"High in favour with everybody, and universally beloved in the GT survey... A hardy energetic young man, ready to undergo any fatigue, and acquire a practical knowledge of all parts of his profession... there are few of my instruments which he cannot manage; and none of my calclulations of which he is not thoroughly master... He can not only apply formulae but investigate them... The ablest pupil that the Hindoo College has yet produced" (Biswas).
\end{abstract}

It is unknown whether Everest ever laid his eyes on the great mountain that bears his name, as Andrew Waugh extended Everest's triangulation network to locate the summit. Waugh's admiration of Everest's achievements led to the naming of "Peak XV" in the Himalayas. After its discovery, Waugh wrote:

\footnotetext{
"here is a mountain most probably the highest in the world without any local name that I can discover", leading him to propose a novel name "in testimony of my affectionate respect for a revered chief, and to perpetuate the memory of that illustrious master of accurate geographical research, this "noble peak" should henceforth be known as Mont [sic] Everest"(Roy, 1986, pp.22-32).
}

Initially, Everest suggested that the Himalayan peaks should retain their local names. He protested that "the natives of India" could not even pronounce his name, nor could it be written in the local Devanagri script. However, Waugh's proposition prevailed and the Royal Geographical Society formally named Peak XV as "Mount Everest" in 1865 after the man who's careful and persistent geodetic measurements established a modern foundation for measuring elevations across the Indian landscape and the Himalayas.

\section{Conclusion}

As the Surveyor General of British India from 1830-1843, Sir George Everest was responsible for completing a substantial portion of 'The Great Trigonometric Survey of India'. He created history through his steadfast work ethic in the mapping of India (Smith, 1999). Even though he never saw the mountain; Mt. Everest is associated with his name because of Andrew Waugh's respect and gratitude for his predecessor. However, it was Radhanath Sikdar, an Indian who assisted Everest in his survey of India, who actually discovered and first calculated the height of Mt. Everest. We believe that Mt Everest should also be recognized as "Mt Sikdar" and it deserves to be mentioned in historical accounts.

\section{BibliograPHY}

Biswas, S. The Man Who 'discovered' Everest: Available from: http://news.bbc.co.uk/2/hi/south_asia/ 3193576.stm. [Retrieved on October 10, 2013]

Gobar Times. Great Arcs: Available from: http:// www.gobartimes.org/content/great-arcs. [Retrieved on October 10, 2013].

Mishra, SK. Trikamji, B. The Medical Maladies of Sir George Everest during the Great Trigonometric Survey of India, IJHS, 49.1 (2014) 42-49.

Kulkarni, MN. Geodesy in India: From Triangulation to GPS: Available from: http://www.gisdevelopment.net/ technology/survey/kulk_1.htm. [Retrieved on October 10, 2013].

Kunzru, H. Mapping Everest. Available from http:// www.bbc.co.uk/programmes/b0074phg, [Retrieved on October 10, 2013]

Lee, S. The Dictionary of National Biography. Vol. 60, Macmillan, New York, 1899.

Phillimore, RH. Historical Records of the Survey of India. Vol. III 1815-1830., 1954

Roy, RD. The Great Trigonometrical Survey of India in a Historical Perspective. IJHS 21.1(1986): 22-32.

Smith JR. Everest. The Man and the Mountain. Whittles Publishing Caithness, 1999. 